\title{
The Importance of Multicultural Education in Schools in the Era of ASEAN Economic Community
}

\author{
Imron Arifin $^{1} \&$ Agustinus Hermino ${ }^{2}$ \\ ${ }^{1}$ State University of Malang, Indonesia \\ ${ }^{2}$ Kanjuruhan University, Malang, Indonesia \\ Correspondence: Agustinus Hermino, Kanjuruhan University, Malang Indonesia. E-mail: \\ agustinus_hermino@yahoo.com
}

Received: January 22, 2017

Accepted: February 13, 2017 Online Published: March 24, 2017

doi:10.5539/ass.v13n4p78

URL: https://doi.org/10.5539/ass.v13n4p78

\begin{abstract}
The purpose of this paper is to provide an understanding importance of multicultural education for students in the schools relate with diversity in the era of Asean Economic Community. The ASEAN, which groups eleven countries, is a very diverse region, with different dynamics that are owned by their respective countries, particularly when associated with education. Diversities can be seen from the many islands, ethnicity, culture, language and religion. Regardless all those differences, these eleven countries share a similar emphasis on human resource development as a key in developing the whole nation to enter the knowledge-based economy and global environment. Pluralism that is the one of the power and uniqueness in the ASEAN Economic Community that can be interpreted as diversity in unity. Diversity, on the one hand is a blessing, because it actually reflects the diversity of the wealth of cultural treasures. But on the other hand, diversity is also great potential for growing proliferation of conflicts, particularly if such diversity is not able to run well. To build the ASEAN community who recognize and appreciate the differences required processes and better understanding through relevant education. Education, as a fundamental human right, is considered very important and strategic for developing their human resources. The right to education imposes an obligation upon countries to ensure that all children and citizens have opportunities to meet their basic learning needs. Promoting quality and equity education is a common policy for countries regardless their different levels of development. Herein lies the importance of multicultural education. Multicultural education becomes strategic for ASEAN nations to be able to manage the plurality creatively, and can be interpreted as an internalization process of values in educational institutions.
\end{abstract}

Keywords: cultural diversity, multicultural education, ASEAN Economic Community, character education

\section{Introduction}

Globalization will affect the nation and the state, society and even individuals in society. The effect of globalization on a nation occurred in various fields, including in the field of education. In education, globalization has a major influence on educational change, both system and curriculum applied.

In addition to the impact of globalization which must be dealt with, the world of education have a new challenge to be faced is competing in the ASEAN Economic Community (AEC). Education condition in some countries of ASEAN ready or not ready adamant to take part in the current global capitalization in the domain of applicability MEA. In application of few of the policy is taken more or less related to education, because it is assumed through education labor-power printed with the competencies that are expected to compete globally.

Southeast Asia is a region covering $4.889 .942 \mathrm{sq} \mathrm{km}$ which consist of 3,219.506 sq km land and the rest, $1,670,436 \mathrm{sq} \mathrm{km}$ is water. It has eleven member countries (Brunei Darussalam, Cambodia, Indonesia, Lao PDR, Malaysia, Myanmar, Philippines, Singapore, Thailand, Vietnam and Timor Leste), with a combined total population of around 556 million. The number of population varies from the fourth world populous country like Indonesia with 241 million people to the least populace country like Brunei Darussalam (372,361, July 2015 est.). They are different not only in terms of number of population but also in terms of geography, culture, and level of socio-economic development.

Regardless all those differences, these eleven countries share a similar emphasis on human resource development as a key in developing the whole nation to enter the knowledge-based economy and global environment. It is 
realized that we are moving fast forward the situation in which all nations operate in a global market environment. No country can grow in isolation. ASEAN countries are facing unprecedented challenges, brought by the convergent impacts of globalization, the increasing importance of knowledge as a principal driver of growth and the ICT revolution. Education, as a fundamental human right, is considered very important and strategic for developing their human resources. The right to education imposes an obligation upon countries to ensure that all children and citizens have opportunities to meet their basic learning needs. Promoting Multicultural Education, Quality and Equity Education is a common policy for countries in Southeast Asia region regardless their different levels of development.

\section{Method}

This paper is aimed to get an understanding importance of multicultural education for students in the schools relate with diversity in the era of Asean Economic Community within the school level to produce a quality education entered the era of the ASEAN Economic Community (AEC). Meanings of the data was based on the depth of the facts obtained in the study by researchers before, which then meant to get the meaning of a suitable and relevant to the situation in Indonesia.

In-depth discussion is supported by the results of research or opinions by previous researchers were consistent with that proposed by Creswell (2009: 25), that: "The literature review accomplishes several purposes. It shares with the reader the result of other studies that are closely related to the on being undertaken", which the statement can be interpreted that the amount of resources will be able to read the relevant support of the meaningfulness of a study that will produce in-depth analysis.

As well as McAlpine \& Amundsen (2011: 211), that: "We must recognize that we benefit as well and will be able to apply our learning to various academic roles (researchers, supervisors, teachers, program directors). This approach to knowledge and identity development has the potential to bring about individual change in ways of thinking and acting, even if institutional change is not yet an outcome". As for the statement can be interpreted that the amount of learning and information from various scholars will enrich our study to analyze a study which will certainly contribute to new discoveries that have not been there before or reinforce previous findings.

Furthermore, Mertens (2010: 225) also affirmed regarding qualitative research, that: "There are key words associated with qualitative methods include complexity, contextual, exploration, discovery, and inductive logic", which the statement can be interpreted that the complexity in qualitative research and in-depth analysis of discernment, will be able to produce an in-depth research discoveries meaning anyway.

Based on various scientific opinion on the above, the results of the discussion in this study is expected to find meaning and contribute to the relevant findings.

\section{The Problem of Quality Education relate with Multicultural Education}

To understand the issue of quality in education relate with multicultural education, it can be seen that education as a system with all its interdependent components: inputs, process, outputs and feedback. Under the inputs, students as raw inputs and curriculum, learning materials, teachers, principals and other educational resource persons, learning facilities and environment as instrumental inputs. The second component, process, is where all inputs interact in the process of teaching-learning to reach educational goals and objectives. The third component, output, is the product of the interaction among the inputs, which can be seen from the student's improved performances in terms of cognitive, affective, psychomotor domain. Feedback mechanism is another important component of the education system that will give us information on how the system succeeds or fails in achieving goals and objectives.

Teachers are essential players in promoting quality education. Well trained, highly motivated, dedicated and professionally competent teachers are very important. This is strongly related to the financial and habit reward they get from their profession as teachers. What is important in improving the quality of education is not only having enough number of teachers in school and class, but enough number of good quality teachers which are highly motivated and dedicated to their jobs. This region has a shortage of teachers both in number and quality.

Multicultural education refers to the learning of appropriate knowledge, attitudes and skills related to the respect and appreciation of different cultures and other differences which include race, ethnicity, religion etc. Gollnick and Chinn (1990) recommend five goals for multicultural education. These goals also emphasize issues beyond the boundaries of ethnic or racial issues. They include: i) the promotion of strength and value of cultural diversity, ii) an emphasis on human rights and respect for those who are different from oneself, iii) the acceptance of alternative life choices for people, iv) the promotion of social justice and equality for all people, and v) an emphasis on equal distribution of power and income among groups. For most intents and purposes the focus of 
this article is on the first two. Most large societies often have subcultures or groups of people with distinct sets of behavior and beliefs that differentiate them from a larger culture of which they are a part. The subculture may be different because of the age of its members, their race, ethnicity, or class. The qualities that determine a subculture as distinct may be aesthetic, religious, occupational, political, sexual or a combination of these factors. At first glance, it may seem that only in countries whose population is made up many different cultural communities that the issue of multicultural education seems pertinent. Hence in predominantly mono-cultural or bicultural societies, there is no need to study other cultures. This myth is pervasive in such societies. However with the phenomenon of transmigration, the world becoming a borderless village, increasing interdependence among countries, and the ominous threat of a "clash of civilizations" the issue of multiculturalism and its place in education is becoming more important. A deliberate and conscious effort has to be undertaken to promote respect and not just mere tolerance for differences, including cultural ones which make up the most contentious of differences amongst mankind. This imperative was officially declared even as early as the Swann Report (DES, 1985) which emphasized the need to teach all young people how to respect ethnic and cultural differences and to accept them as part of the cultural richness of life in our modern world, and not as a threat.

\section{Cultural Diversity and Multiculturalism}

To build character we can strengthen community identity and resilience of ASEAN are multi-cultural, which has a wide variety of cultures. Cultural diversity is one of the nation's wealth in ASEAN, which became one of the foundation in and the nation in the ASEAN region, including in the development of educational programs.

Recognition of cultural diversity was almost as congruent with the principles of multiculturalism, which is based on the 'politics of recognition', recognizes every citizen has equal footing with each other. No less important, the recognition of diversity is based on the principle of mutual respect and respect in the midst of differences (Mitaray, 2000; Banks, 2004, Bokhorst-Heng, 2007).

Cultural diversity and multi-culturalism in ASEAN can give color to each of the entities and cultural groups that exist in each ASEAN member country, and at the same time will encourage the asean economic community to promote education in the principles of understanding in diversity. Therefore, awards cultural diversity should not be considered complete or allowed to develop by itself; instead they should be reinforced constantly through various channels of social interaction and education at various levels.

In the context of cultural diversity and the multicultural nations in the ASEAN needs to reinforce and internalize the values, such as: identity and resilience; personality and strong character; cling to democratic values and civility; high appreciation of the law and order; social justice, politics, and economics; have a formal individual piety and piety communal-social as well; civilized (civility) in the sphere of civil society; appreciate diversity and multicultural life; and have a perspective of local, national and global at the same time.

Furthermore, it can be interpreted that the ASEAN community that has cultural diversity and multicultural is a plural society have fundamental characteristics such as: (1) promoting mutual respect; (2) understanding life together lasting territories; and (3) to support each other's progress and strength of the economy and education.

\section{Multicultural Education}

The roots of multicultural education, coming from the attention of a US education experts, Prudence Crandall (1803-1890) are intensively propagate views on the significance of the background of learners, both in terms of aspects of culture, ethnicity, and religion. Educational attention in earnest background of learners is the forerunner for the emergence of multicultural education (Banks, 2008).

Thus, in general, is the concept of multicultural education and practical education that attempts to provide an understanding of the diversity of race, ethnicity, and culture in a society. The goal is for people to live in peace among communities of different racial, ethnic, cultural, and religious differences (Charlesworth, 2008).

Multicultural comes from the word that means lots and multi-cultural/ culture that means the culture or customs. Gorski (2005) defines multiculturalism comes from the root word multi (many), culture (cultural, and culturalism). Essentially, the multiculturalism entails recognition of the dignity of human beings who live in the community with the culture of each unique. This means that the concept of multiculturalism implies that every human being with various tribes, religions, races, customs and traditions are valued and respected presence in the life of a nation and the state. this means there is no view that the same care should be contested, but should seen as a diversity that must be knitted as well in order to give a sense of beauty, comfort, peace, harmony, and a sense of security. According Mason (2013) mentioned that multiculturalism is an honest effort to organize pluralistic society into a multicultural society that is harmonious at once dynamic because their respect for freedom and human equality. In this case multiculturalism emerged as an attempt to build a harmonious society 
(secure, peaceful, tolerant) which has a multi-cultural (traditional, religion, race, ethnicity) in order to live together in peace and harmony. Thus we need an honest effort of the organizers of the country (the legislative, executive and judicial) to manage the community of nations in order to manifest the life of a harmonious society (tolerant, harmonious, peaceful) in the diverse cultures, religions, races, customs, and arts and culture).

Andersen and Cusher (1994) in Tilaar (2004) states that multicultural education can be defined as education about cultural diversity. Then, Hermino (2014) defines multicultural education as education that want to explore the differences as a gift from God, and we are able to address these differences with a full-tolerant. Similarly, Gorski \& Pothini (2014) argues that simply multicultural education is education about the diversity of cultures in response to demographic and cultural changes in a specific community or even the world globally.

Multicultural education is a synthesis of anti-racist education approach and multi-cultures used internationally in the 60s to 90s (Hoffman, 1996). In ASEAN since its inception has had a lot of diversity of culture, ethnicity, language and religion. It is this diversity that is often termed multicultural or intercultural. Both terms describe a situation where there are a lot of culture in a country (Tilaar, 2004).

Furthermore, Gorski \& Pothini (2014) stated that the underlying goal of multikultural education is to effect social change. The pathway toward this goal incorporates the strands of transforation: (1) the transformation of self; (2) the transformation of schools and schooling; and (3) the transformation of society.

Based on the understanding of the above it can be interpreted that the purpose of multicultural education is to be able to respect cultural diversity and encourage them significantly to be able to recognize and eliminate prejudice and discrimination that already exists. In essence, multicultural education has five focal issues, such as: (1) the process of education that respects, recognizes and celebrates the differences in all areas of human life. Multicultural education stimulate students to the fact that developed in the community, which is a way of life, customs, culture, all of which have enriched human life; and (2) the process of applying equation balance education and human rights, discrimination against injustice and voicing values that build balance; (3) Multicultural education is based on the pedagogic teachers, pedagogic based on human equality (equity pedagogy); (4) multicultural education aimed at the realization of human intelligent in ASEAN community especially for students during learning process in the school; and (5) the principle of globalization.

\section{The Role of Family}

Hermino (2016) mentioned "If there is righteousness in the heart, there will be beauty in the character; if there is beauty in the character, there will be harmony in the home; if there is harmony in the home, there will be order in the nation; if there is order in the nation, there will be peace in the world".

Considering various dynamics of globalization in the field of education today which affect the lives of children in particular, the character education is a very important and strategic step in rebuilding the identity of Asean Economic Community and mobilize society formation Asean stronger. But it is important to stress that character education should involve all stakeholders, such as households and families; school; and the wider school environment (society). Therefore, the first step to do is reconnect relations and educational networks barely connected between the three environmental education. Formation of character and character education is not going to work for between three educational environment there is no continuity and harmonization.

Schools, in essence not just a "transfer of knowledge" itself. As stated by Erik, et al (2014), that the school is not solely a place where teachers impart knowledge through a variety of subjects. Schools also are institutions that seek business and process oriented learning on the value (value-oriented enterprise). Furthermore, Rama (2015) also stated that the organization of a school system in itself was an effort of moral (moral enterprise), because it is a deliberate effort to control the pattern of human society development.

Formation of character and character education through schools, thus, can not be done solely through the learning of knowledge, but it is through planting or values education. In general, studies on the value usually includes two key areas, aesthetics, and ethics. Aesthetics refers to matters of and justification for what he viewed humans as "beautiful", what they enjoy. While ethics refers to things on and justification of appropriate behavior according to the standards prevailing in society, whether they are from the religion, customs, conventions, and so on. And those standards are moral values or morals about which actions are good and which are bad.

ASEAN comprehensive community clearly has a major influence on the success of planting aesthetic values and ethics for the formation of character, especially to students in school. From the perspective of educational management, Gardner, et al (2008) argues that the social situation with the value system espoused, influence the attitudes and perspectives of society as a whole. If the system of values and their view is limited to the "here and now", the efforts and ambitions are limited to the here and now as well. 
In that context, the meaning of values in character education emphasizing togetherness member concerning the same historical experience, common objectives, the same steps, the same solidarity. Here, the importance of education in the family to bring a shared responsibility in upholding the values of good and prevent bad values that starts within the family to children, which will be useful for the development of life in the future.

Core value of multicultural education is reminiscent of the importance of multicultural education that includes four dimensions; dimensional man with God, man and man, man and the universe, and man with himself.

\section{Educational Value}

The formation of character is part of the educational value through school is a noble effort is urgently required. In fact, if we talk about the future, the school is responsible not only in print learners who excel in science and technology, but also the identity, character and personality. And it is relevant and contextual not only in countries that are experiencing a crisis of character, but also for developed countries even (McGill, 2013; Yuan, 2011; Jayne, et al, 2015).

Enterprises character formation through the school, in addition to character education simultaneously can also be done through education of values with the following steps: first, apply a "modeling" or "exemplary", Ie, socialize and familiarize school environment to revive and uphold moral values and moral right through the model or example. Each of teachers and other educational staff on school premises let to become role models of life (living exemplary) for each learner. They must also be open and ready to discuss with the students about the values of the good.

Second, explain or clarify to the students constantly about the value of the good and the bad. This effort could be accompanied by the measures; reward and cherising good values and otherwise denounce and prevent the enactment of bad values; affirm the values of good and bad in an open and continuous; provide opportunities for learners to choose different alternatives based on the attitudes and actions; perform free choice after a deep weigh the consequences of every choice and action; familiarize behave and act on good intentions and prejudices and objectives of the ideal; familiarize behave and act with good patterns are repeated continuously and consistently.

Third, apply a character-based education. This can be done by applying a character-based approach into each subject existing value in addition to specialized subjects for character education, such as religious studies, civics, history, art and culture. Looking at the criticism of these subjects, it is necessary to reorient both in terms of content and approach, so that they not only be verbal and mere rote, but actually managed to help reestablish the character and identity of the nation.

Immediately obvious, character education related to other fields, especially in culture, education, and religion. All of the three areas of past life is closely linked with the values were very important for people in various aspects of life. Culture or culture generally include the noble values that have traditionally been the role model for the community. Education-in addition to covering the transfer and transmission of knowledge-is also a very strategic process in instilling values in order civilizing human child. Meanwhile, the teaching of religion also contains a variety of noble values for humans to achieve human dignity and culture.

Observing the foregoing, it is clear that the meaning of values in character education related to other fields, especially in culture, education, and religion. All of the three areas of past life is closely linked with the values were very important for people in various aspects of life. Culture or culture generally include the noble values that have traditionally been the role model for the community (Jayne et al., 2015; Camicia, 2009; Slavin, 2006). Education-in addition to covering the transfer and transmission of knowledge-is also a very strategic process in instilling values in order civilizing human child. Meanwhile, the teaching of religion also contains a variety of noble values for humans to achieve human dignity and culture (Duke, 2000; Epstein et al., 2002; Fullan, 2007).

\section{Transformational Education Leadership in the Globalization Era of ASEAN Economic Community}

The word globalization is derived from the word global, which literally means global or universal, comprehensive, universal. The word then became a term which refers to a kedaan where a country with other countries have been fused. Territorial boundaries, cultural, and so is already not an obstacle anymore to perform the unification. Thus literally, globalization means the merging of the various countries that exist on this globe into a single entity. Globalization is a process of making something (an object or behavior) as a characteristic of every individual in this world without being restricted by region (Schein, 1985; Reeves, 2006; Stromquist, 2002; Mason, 2013)

With regard to transformational leadership, then according to Robbins (2005), transformational leadership is leadership where the leader is able to inspire the staff her to be able to prioritize the progress of the organization 
of the personal interest, and able to provide good care to its staff and is able to change the consciousness of the the staff to be able to cooperate to the fullest and see the organization as a whole unity of view to achieve the goal.

Bass \& Riggio (2006) defines transformational leadership is a form of leadership in which the leader is able to expand and improve working interest of its members, or the system of leadership where leaders are capable of triggering sensitivity and acceptance of vision, mission and goals of the organization, and where the leader has control over its members to be able explore their potential for the progress of each organization.

Based on the thought above, then in the face of education in the era of globalization are increasingly complex and with high competitiveness, it is necessary educational leaders who can transform charisma, inspiration, intellectual stimulant, and individual consideration to the interests of the staff as a whole and the development of educational institutions led in accordance with the vision, mission and educational goals to be achieved (Soutworth, 2002; Hallinger, 2003; Moolenaar et al., 2010; Balyer, 2012; Rodriguez, 2014).

Referring to the above understanding, the transformational leadership in the field of education, especially in Indonesia in addressing the globalization era in the arena of the ASEAN Economic Community (AEC) is a leadership that can combine three behaviors, the charisma, individualized consideration and intellectual stimulation.

Furthermore, that when education is involved welcoming the ASEAN single market in 2015, the leadership role of transformational education is to prepare skilled human resources, sensitive and critical. Skilled work, sensitive and critical issues in the role. The third skill is absolutely present in Asean single market. Single market in the era of globalization can not be understood from the economic aspect, but also from non-economic aspects, one of which is in the field of education (Torres, 2002; Soutworth, 2002; Tatto, 2006; Loomis, et al, 2008; Moolenaar, et al, 2010). That understanding also needs to be built and internalized so that Indonesia became an independent country and dignified. Independent means free from the intervention of other nations in determining the direction of its policies, including policies to educate and welfare of its people through education and dignified means working together with other nations without losing their identity, and this can be optimized through character education in schools.

Competition quality of education in Indonesia also needs to be examined is wise in accordance with the purpose of education in Indonesia. However, the competitive dynamics of global education in ASEAN in the era of the ASEAN Economic Community (AEC) can not be circumvented by the education system in Indonesia, and tumpuhan implementation towards global competition in education is certainly relies on educational leadership who have extensive knowledge, and the concept of leadership can combine logic thinking, analytical thinking, and creative thinking in leading educational institutions which it is responsible. The ability of the educational leaders in the era of globalization, which also requires the freedom to innovate in charge, who mandated him to develop their ideas in a way of leading educational institutions to the maximum (Burbules, 2000; Northouse, 2001).

\section{Acculturation Character Education in the Learning Systems}

One of the key in the dynamics of the globalization of the times in the field of education, is with regard to character education. Character education is very important given to children in schools, it is that the children understand the importance of moral values of humanity and respect for the situation and environmental conditions in the dynamics of the growing progress of education in ASEAN. Character education is very helpful in preparing students into life in the era of globalization. The conditions in line as proposed by Carol Copple, Richard de Lisi, and Irving Sigel as written in Spodek (1982: 3): “... The development of the child is viewed as simple one type of behavioral change. For the leaning theorist, intellectual development consists of an accumulation of gradual learnings, of changes in specific behaviors". The statement can be interpreted that the development of a child's behavior is influenced by the surrounding environment, and it will also affect the outlook and the concept of thinking of children against himself and the surrounding environment.

With regard to the values contained in the learning curriculum, the research conducted by previous researchers (Misco, 2007; Peng et al, 2013; Agrawal, 2013; Mason, 2013) stated that the curriculum used at school- school is the curriculum should be relevant to the needs of the school, both academic interest, as well as with regard to the moral development of the children in the school were still in the rules of the values that characterize education in schools that exist in the face of education in the era of globalization.

Against these values, it is also in line as proposed by Allport, as quoted by Kadarusmadi (1996: 55) states that the value is: "a belief upon which a man acts by preference. It is this a cognitive, a motor, and above all, a deeply 
propriate disposition." Understanding the meaning that it is the belief that human preferences used in action. Humans select or choose activities based on the value of his own beliefs. Similarly Ndraha (1997: 27-28) states that the value is abstract, because it was uncertain value contained in something. Something that contains the value (vehicles) there are four kinds, namely: exercise, behavior, attitude and basic.

The ability of teachers to teach character education in schools, then it is as has been done by previous researchers (Mayer et al, 2004; Chan, 2011; Skaalvik \& Skaalvik, 2013; Kopnina, 2013; Mills \& Quinn, 2013; Twigg, et al, 2013), that it is very necessary to understand the current situation, both the students and in schools. This is important because with a good understanding by teachers when giving lessons at school, where in the subjects contained values of character education to be achieved, then it implies that the teacher had been giving a good understanding for students to how it should be in learning and this can be done from early childhood education. Even the results of the study by Mayer, et.al. (2004) confirmed that with a good understanding of character education for students, it actually has positioned the student is in equilibrium Emotional Intelligence (EI) is good.

Character education in the era of globalization, not only apply to students who are in the urban areas alone or in schools that have students who are heterogeneous, but also applies to all education in all areas. It's like the results of research by previous researchers (Hannum et al, 2013; Sargent et al, 2013; Scherrer, 2013; Twigg, et al, 2013), stated that education in areas far from the city also still need to obtain and understand the importance of character education in schools. However, to schools located far from urban areas, where the culture is still strong upheld as a norm of life. Then teaching character education will not be as difficult as teaching it to students in urban areas, where the mindset and plurality in everyday life may influence the development of personality and behavior of students.

Educational leadership which in this case is the principal, is also a study of the implementation of character education. It's like the results of research by previous researchers (Shockley, 2008; Mills \& Quinn, 2013; Greenberg et al, 2007; Kalargyrou, 2012) is that as a leader of education, the principals should be able to look at the diversity of cultures that exist at the school, both from the students and the school environment, so that the school can position its existence on the situation and the conditions required by the needs of the students, not only in schools alone, but will be taken on a social life outside of school.

\section{Challenges of Multicultural Education in the Globalization on ASEAN Economic Community}

The changes that occur today as the impact of scientific and technological advances as well as the influx of globalization bring multidimensional effect. So it takes a learning approach and a multicultural model with a global perspective to meet the demanding needs of learners, communities and employment in a globalized world.

Global perspective is a perspective or way of thinking to a problem, event or activity from a global perspective, ie from the side of the world or international interest. Therefore, the attitude and actions are also directed to global interests. According Kieu \& Chau (2000), the challenge of education in global perspective, one of which is an understanding of multicultural education is not racist to prepare and support the process of intercultural learning, social development and if necessary class action.

Thus, the world of education in an era of economic society Asean must understand the issues and global issues such as cultural diversity, political, economic, social, conflict and peace, interdependence among nations in the world, human rights, environmental issues such as environmental degradation, disease and migration and others. Banks (2008) argued for the five dimensions that are related to each other must be understood within the meaning of multicultural education, such as: 1) content integration; integrating different cultures and groups to illustrate basic concepts, generalizations and theoretical subjects/ disciplines; 2) the Construction Knowledge Process; bring learners to understand the cultural implications into a lesson; 3) an Equity Paedagogy; to adjust teaching methods by learning to learners. This is done in order to facilitate a student's academic achievement ranging from racial, cultural and social; 4) prejudice reduction; identify the characteristics of the race and determine the methods of education of students; and 5) train learners to berfartisipasi in sports activities and interact with the entire staff and students of different ethnicity and race in an effort to create a culture of academic.

Thus, education can bring multicultural education capable of creating a society that is educated and uneducated, not a society that is away from the social and cultural reality. Therefore, although the multicultural education in asean economic community level requires an approach that is considered more appropriate for asean heterogeneous society, especially in the period of autonomy and decentralization.

Having seen the conditions that exist in the ASEAN community, then multicultural education in the era of 
globalization is currently facing three fundamental challenges: first, hegemony phenomenon that occurs in the world of education due to the tug of war between excellence and affordability. Learners in schools segregated according socioeconomic background, religion and ethnicity. Second, the curriculum is based on gender, social economic status, local culture and geography. This indicates imbalance and bias that restricts awareness of multicultural students. Third, the teacher. Feasibility and competence of teachers is needed to manage learning multiculturalism.

Therefore, in order to multicultural education for ASEAN community can be implemented properly, be aware of the various aspects, such as: 1) a multicultural curriculum, 2) teachers, 3) learning process, and 4) evaluation of learning process by using a multicultural approach. First, in regards with a multicultural curriculum. According Tilaar (2004), curriculum model that can be used in multicultural education curriculum includes "official" and "the hidden curriculum", ie unwritten curriculum and planned, but the process of internalization of values, knowledge and skills would occur among the learners. In the official curriculum, multicultural education should be integrated with all subjects and activities across the curriculum. Instead, insight multiculturalism is not included as an additional burden as a new subject in the curriculum that is already very heavily felt by teachers and learners. Therefore, the model multicultural curriculum should be able to integrate the learning process values, knowledge and skills "live" in a multicultural society, such as: skillfully negotiate, express and confront differences, conflict resolution, cooperative learning and problem solving. Making of the value of education, knowledge and skills can be designed according to the stages of child development and education. Charges multicultural values need to be designed in a learning process strategy that encourages the internalisation of values.

Second, in regards with the teacher. Curriculum development with a multicultural approach must be preceded by a good socialization, to enable teachers to develop curriculum in the form of syllabus and lesson plans, classroom learning and evaluation in accordance with the principles of multiculturalism. This is due to a major determinant of educational success multikuktural are teachers. Therefore, teachers should be familiar with the characteristics of multikulktural education so as to develop the curriculum muktikultural in learning activities which they are responsible. Thus, a teacher through a multicultural approach must be flexible, because to teach in multicultural community in ASEAN, consideration cultural differences are important things that must be the teacher's attention. Factors such as: building the paradigm of diversity inclusive and moderate in school, respect the diversity of language, build a sense of gender sensitivity, build critical understanding of the inequalities and differences in social status, build anti-discrimination ethnic, appreciate their different abilities and appreciate the differences in age must be packed in the realm learning and awareness in schools, so as to create a notion to understand and accept all the differences that exist in every individual learners and in the end the students are expected to have a strong character to be a democratic, pluralist and humanist.

Third, in regards with learning process. The learning process developed should put learners in the surrounding social reality. That is, the learning process that relies on students to learn in groups and compete in groups in a competitive situation positive. In this way, the differences between individuals can be developed as a strength and a group of students used to live with a variety of diverse cultural, social, economic, intellectual and political aspirations. The learning process can be developed, for example: cooperative learning, problem solving, inquiry, etc.

Fourth, in regards with evaluation of learning process by using a multicultural approach. Evaluation used should include all aspects of learners' abilities and personality in accordance with the purpose and content developed. Evaluation tools are used not only to measure learning outcomes (achievement), complete tetapai provide clearer information about the learning process. The use of alternative assessments are considered attempts to integrate the activities of measurement of learning outcomes with the overall learning process, even the assessment itself is an inseparable part of the whole learning process. Performance assessment, portfolio assessment, public assessment, observation guidelines, interview guides, rating scale, the scale of attitudes, check lists, questionnaires and so on as an assessment tool that can be used to evaluate the learning that uses a multicultural approach.

\section{Challenges for the Teacher in the Complexity of Education}

Examine the dynamics of education in the era of globalization this time then there are three things that are interesting to observe, namely: 1) the role of teacher professionalism as an educator; 2) neoliberalism education; and 3) education in the era of globalization. Those three things, means that education rests on teachers. It also means that teachers engage themselves professionally in educational activities, ground-floor activities of certain kind. The teach in various ways: they set tasks for pupils, they try to motivate pupils, to help them, to control 
their performances, and to improve their understanding and skills.

First, with regard to the professionalism of teachers. It is inevitable that the quality of education is determined by a variety of interrelated factors. Where the factors that determine the education process in a school is located in the dynamic elements that exist in the schools as well as the environment as a unified system. One such element is the teacher as the leading actors in the implementation of education at the institutional level and instructional. Observing that the role of the teacher in relation to the quality of education, at least can be seen from the four dimensions, namely as a private teacher, the teacher as an element of the family, as an element of teacher education, and teachers as part of the community.

The teacher as a person, then it is self-realization with all the unique characteristics that correspond with the position as stakeholders teaching profession. Thus, teachers must be able to know himself and is able to develop towards the realization of healthy personal and plenary (fully functioning person).

Teacher as an element of the family, the teacher role is to build a strong family so that it becomes the foundation for its performance in exercising its functions as a component of teacher education. To realize a strong family life, it should be supported among others by: a strong religious foundation, adjustment healthy marriage, the atmosphere and the inter relationship between family harmony, economic prosperity was good, and the pattern of effective family education.

Teachers as elements of education, the teacher's role in the overall educational activities at the operational level, is a determinant of educational success, where as an educator in the school, teachers do the tasks education performance in the guidance, instruction, and training. All activities are strongly associated with the development efforts of the learners through the example, the creation of a conducive educational environment, guide, teach, and train learners.

Teacher as an element of society, it is the teacher's role as mediators between society and education, especially in schools. In this regard, the teacher will lead and develop a variety of educational efforts in schools into life in society, and also brought public life to a school, so the teacher's role in efforts to develop educational get a place of concern in the community or the environment.

Second, neoliberalism education. As a consequence of the development of global free trade, one of the challenges faced by the world of education is their propensity to make education as a commodity that makes its development is a pattern of privatization, which transfer the waiter education to the private sector, and commercialization, ie applying the patterns of the market approach in institutions public. In view of the level of education as a commodity, will cause a shift that makes education an elitist, which can be interpreted only be enjoyed by the certain course that is able to pay, when it should be the education it populist that should be enjoyed by everyone in accordance with their own right. Thus it can be interpreted that the first function of education in human society, in point of time, is to direct and Accelerate learning in such a way that the rising generation will be well prepared for adult life.

Third, education in the era of globalization. It should be observed with regard to the present era of globalization, is about multicultural education, that multicultural education is the transmission of values, knowledge, attitudes, and behaviors directed against an individual or group within a society, so that while respecting the cultural diversity that comes from ethnic differences, religion, culture, language, and region, and at the same time support the policy agreed. Referring to these conditions, the role of teachers in multicultural education needs to be interpreted as a manifestation of the educational strategy still emphasizes harmony and harmony situation and condition of the school and the community dynamic in all areas, which require teachers who understand well acculturation local circumstances. In the present era of globalization, the development of the teachers not only on aspects of intellectual ability, but also on the ability of social interaction, religious, as well as an understanding of the development of science and technology, so that it can think and act concretely in accordance with its responsibilities as education.

Interpret the above explanation, the education in ASEAN can continue to compete in quality improvement, and especially on the role of the educator or teacher can position as a person who has self understanding, has self-acceptance, has self direction, and self realization, so their role can be maximized as an educator. If it is so then the teacher is a person who can be as a role model.

\section{Role of the School Principal}

The principal's role in leading the school has three functions, namely as leaders and managers in the field of education in schools they lead; as school leaders to menakodai the wheels of school organization and produce top students and virtuous character well; and as the protector of all citizens of the school in order to jointly work 
together to promote education in the school. This condition is also as stated by John C. Maxwell in Simon (2010: 16) that in order to progress in the leadership of the school, the principals need to prioritize the interests of the school. The true leader is serving, that is to serve others, serve their interests, and in doing so will not always be popular, not always impressive. Opinion was also in line with that set forth in Mulyasa (2011: 67) that simply school leadership can be interpreted as a way or business principals to influence, encourage, guide, direct, empower and mobilize teachers, staff, students, parents of participants students, school committee, board of education, and other relevant parties, to achieve the goal of character education.

With regard to his leadership, the school principal as a leader as well as managers in the implementation of character education in schools, and the teacher is a leader and manager in the implementation of character education in the classroom (Wiyani, 2012: 68). The school principal giving instructions to teachers to lead and manage students through the transformation of the noble values based on the existing rules and peculiarities of educational values that exist in the school. Against this also as stated World Bank (1999) in Rival \& Murni (2009: 789) "Give people a handout or a tool, and they will live a little better. Give them an education, and they will change the world ". Against this, the principals at the schools need to emphasize to teachers to prepare a lesson plan with good character and include indicators to be achieved in the learning.

\section{Role of Teachers in Classroom Level}

Teacher plays a very strategic especially in shaping the character and developing students' potential. The existence of a reliable teacher at the school, both behaviorally and academically during the learning will position the teacher as someone who eligible to become as a role model and imitated. At the school in general, the role of the teacher as a role model will be very visible. This is because the school teacher is a source of knowledge for students. Character development is not only limited in the habit of advising students. Characters just formed by the contiguity quality of personality in the process of learning together (Noor, 2012: 124).

At the level of the class, the teacher is an important factor that is big influence on the success of character education in schools, even critical to the success of students in developing personal intact (Mulyasa, 2011: 63). Say so, because teachers are the main figures and examples and role models for students. Therefore, in character education teachers should start from himself to anything he does well be good anyway influence on students.

Teachers at the level of the classroom and the school also served to provide exemplary early students. Their exemplary and discourse exemplified by the principal at his school, and it is also in line with that proposed by Dakir (2010: 101): ".... Planting sense of right and further that such measures can be implemented, it is expected for learners will have an attitude, then the value, and eventually formed a personality who religious".

With regard to the preparation of lesson plan, the teacher in this case must be carefully and professional character values that can be achieved by the students. In this, the teacher should also be able to integrate the condition of schools on learning done in class, so the lesson plan that has been prepared by teachers and approved by the school principal can be performed well. Against this, Fitri (2012: 46) also suggests that the strategy of character education can be seen in four of integration, namely: 1) integration into subjects, 2) integration through thematic learning, 3) integration through the creation of an atmosphere in character and habituation, 4) integration through extracurricular activities, 5) integration between school education programs, families, and communities.

On the other hand, the role of parental involvement is a necessity in the school to support the implementation of character education programs, as well as one of concern from school to help cope with the students who have problems, so that problems can be solved and students can learn and achieve in school the. It also points out Hamalik (2010: 183) that teachers play a major role and is responsible for guiding the students to develop their potential and help solve problems and difficulties, with the intention that the student is able to independently guide him/herself.

\section{Problem of Quality Education}

To understand the issue of quality in education it will be easier for us if we look at education as a system with all its interdependent components: inputs, process, outputs and feedback. Under the inputs we have students as raw inputs and curriculum, learning materials, teachers, principals and other educational resource persons, learning facilities and environment as instrumental inputs. The second component, process, is where all inputs interact in the process of teaching-learning to reach educational goals and objectives. The third component, output, is the product of the interaction among the inputs, which can be seen from the student's improved performances in terms of cognitive, affective, psychomotor domain. Feedback mechanism is another important component of the education system that will give us information on how the system succeeds or fails in achieving goals and 
objectives.

Quality in education cannot be seen from the output or student learning achievement only, but from other components as well. If we follow the Dakar's Framework of Action, then the definition of quality is no longer focused only on teaching learning and the classroom. A good quality multicultural education in requires: 1) healthy, well nourished and motivated students; 2) well motivated and professionally competent teacher; 3) active learning techniques; 4) a relevant curriculum; 5) adequate, environmentally friendly and easily accessible facilities; 6) healthy, safe and protective learning environments; 7) a clear definition and accurate assessment of learning outcomes, including knowledge, skills, attitude and values; 8) participatory governance and management; and 9) respect for and engagement with local communities and cultures. (World Education Forum Drafting Committee, 2000).

We cannot expect to have good quality education if the students are not healthy, malnourished, going to school with empty stomachs. Their basic need for food will decrease their attention and motivation from learning. The significant number of people living below the poverty line in the region needs real actions if we really want to improve the quality of education.

Teachers are essential players in promoting quality education. Well trained, highly motivated, dedicated and professionally competent teachers are very important. This is strongly related to the financial reward they get from their profession as teachers. What is important in improving the quality of education is not only having enough number of teachers in school and class, but enough number of good quality teachers which are highly motivated and dedicated to their jobs. This region has a shortage of teachers both in number and quality. In most of the countries, teaching is not an attractive profession financially.

Indonesia has made significant progress in expanding access to primary and secondary schooling in the past ten years. In contrast to access gains, quality improvement has been broadly disappointing. In particular, there appear to be serious urban-rural quality gaps. Roughly one-half of primary school teachers have had little professional training; only two-thirds have completed lower secondary schooling.

The teaching learning process should put the students as subject not as an object. Students must be active in learning and they should not only learn about subject matters but also to learn how to learn. Teachers should play their new role in preparing students for an emerging knowledge-based and technology-driven economy. It is unrealistic to expect the low quality and less dedicated teachers to perform this new role.

A relevant curriculum, which addresses the need of students, community and work place, should be used in good quality education. In most of the countries it is considered that curriculum is overloaded and should be reformed. Mismatching between what students learn at school and what the community or world of work demands is also an issue to address. This is the irrelevant curriculum and teaching learning process that contribute to the widening gap between education institutions and world of work, and finally contributes to increasing unemployment rate.

In majority of the countries we are still lacking learning facilities such as textbooks, libraries, laboratory, and other learning materials both in number and quality. For example, most schools in the more developed rural areas lack of the teaching equipment required by standardization of the Ministry of Education, Libraries remain poorly stocked and out of date. Many schools are yet to get a science laboratory (Finn, et al, 2003).

Not all schools and classrooms in our education institutions are healthy and conducive enough to promote excellence in learning. We need a better governance of education systems that is efficient, accountable, transparent and flexible so that they can respond more effectively to the diverse and continually changing needs of learners and community.

\section{Clossing}

Globalization is a powerful influence and appears on the dynamic development of education in school, and has also made its way into educational policy in the countries of the ASEAN region in general and the national level. Another aspect that poses as a challenge to educators relate with multicultural education is the continuity and consistency of messages that children receive between school and home. In this context, it is vital that families and parents themselves are supportive of the ethos of multiculturalism so as not to contradict or work against what is being learned in schools. Families sometimes inadvertently, consciously or unconsciously, contribute to children's bias and prejudice towards people of other cultures. They do this in three main ways: direct tuition, indirect tuition and role-learning. In direct tuition, parents and other family members tell children what is "right" and what is "wrong"; what they should say and do in specific situations. Indirect tuition occurs unintentionally when children spontaneously imitate a family member's behavior, while role-learning involves teaching children 
who they are and how to behave towards others and an understanding of the roles of others.

From all of the above it can be concluded that there are entering the era of the ASEAN Economic Community (AEC) today as globalization brings attention to the area of scrutiny for education in the ASEAN Countries in particular, which give more attention such as: first, the power of the ASEAN community one of them is because of the complexity. This diversity, on the one hand is a blessing, because it actually reflects the pluralism wealth of cultural treasures. But on the other hand, a plurality also has great potential for growing proliferation of conflicts, particularly if such diversity is not able to run well.

Second, to build a society that acknowledges and respects differences educational process is required. And multicultural education to be very strategic to be able to manage the plurality creatively. It should multicultural education is a process of internalization of the values of multiculturalism itself in educational institutions.

Third, the education in the era of the ASEAN economic community must understand the issues and global issues such as cultural diversity, political, economic, social, conflict and peace, interdependence among nations in the world, human rights, environmental issues such as environmental degradation, disease and migration of the population and so forth.

Fourth, In order for multicultural education in ASEAN can be implemented properly, it must pay attention to various aspects, among others: a multicultural curriculum, teaching staff (teachers), the learning process and evaluation of learning by using a multicultural approach

Multicultural education in the ASEAN economic community should be carried out by the forward four principles: sincerity, honesty, openness, and comitmment themselves. With the meaning of these four ASEAN nations will be able to implement multicultural education that is based on the absence of adverse interests of other nations, and it can be a learning experience for the nations outside ASEAN to live in unity and peace.

\section{References}

Agrawal, T. (2013). Educational inequality in rural and urban India. International Journal of Educational Development, (34), 11-19.

Balyer, A. (2012). Transformational Leadership Behaviors of School Principals: A Qualitative Research Based on Teachers' Perceptions. International Online Journal of Educational Sciences, 4(3), 581-591.

Banks, J. A. (2004). Multicultural Education: Historical Development, Dimensions, and Practice. San Francisco: Jossey-Bass.

Banks, J. A. (2008). An Introduction to Multicultural Education (4th ed.). Boston: Pearson Education.

Bass, B. M., \& Riggio, R. E. (2006). Transformational Leadership (2nd ed.). New York: Routledge.

Bokhorst-Heng, W. (2007). Multiculturalism's Narratives in Singapore and Canada: Exploring a Model for Comparative Multiculturalism and Multicultural Education. Journal of Curriculum Studies, 39(6), 629-658. https://doi.org/10.1080/00220270701506324

Burbules, N. C., \& Torres, C. A. (2000). Globalization and education: Critical perspectives. New York: Routledge.

Camicia, S. P. (2009). Identifying Soft Democratic Education: Uncovering the Range of Civic and Cultural

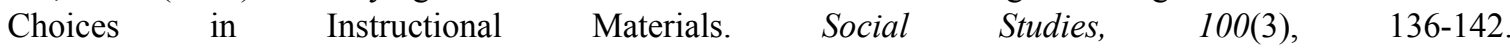
https://doi.org/10.3200/TSSS.100.3.136-142

Chan, A. (2011). Critical multiculturalism: Supporting early childhood teachers to work with diverse immigrant families. International Research in Early Childhood Education Journal (Online), 2(1), 63.

Charlesworth, Z. (2008). Learning styles across cultures: suggestions for educators. Education and Training, 50(2), 115-127. https://doi.org/10.1108/00400910810862100

Creswell, J. W. (2009). Research Design. Qualitative, Quantitative, and Mixed Method Approaches. Los Angeles: SAGE Publications, Inc.

Dakir, H. (2010). Planning and Curriculum Development. Jakarta: Rineka Cipta.

DES. (1985). Education for All: Report of the Committee of Inquiry into the Education of Children from Ethnic Minority Group (The Swann Report). Department of Education and Science, Cmnd 9453, London, HMSO

Duke, N. K. (2000). For the Rich It's Richer: Prints Experiences and Environments Affered to Children in Very Low and Very High Socioeconomic Status First Grade Classroom. American Educational Research Journal, 37(2), 441-478. https://doi.org/10.3102/00028312037002441 
Epstein, J. L., Sanders, M. G., Salinas, K., Simon, B., Vanvoorhis, F., \& Jansoon, N. (2002). School, Family and Community Partnership: Your Handbook for Action (2nd ed.). California: Corwin.

Erik, M., Hines, L., DiAnne, B., Laura, M. G., Gonzalez, J.V., \& Alia, H. (2014). Parental involvement in college planning: Cultural considerations when working with African American families. Journal for Multicultural Education, 8(4), 249-260. https://doi.org/10.1108/JME-06-2014-0025

Finn, J. D., Pannozzo, G. M., \& Achilles, C. M. (2003). The "Why's" of Class Size: Student Behavior in Small Classes. Review of Educational Research, 73(3), 321-368. https://doi.org/10.3102/00346543073003321

Fitri, A. Z. (2012). Character Education Based Values \& Ethics in Schools. Jogyakarta: Ar-Ruzz Media.

Fullan, M. (2007). New Meaning of Educational Change. New York: Teachers College Press.

Gardner, R., Karakasoğlus, Y., \& Luchtenberg, S. (2008). Islamophobia in the Media: A Response from $\begin{array}{lllll}\text { Multicultural Education. Intercultural 119-136. } & \text { Education, }\end{array}$ https://doi.org/10.1080/14675980801889658

Gollnick, D., \& Chinn, P. (1990). Multicultural Education in a Pluralistic Society (3rd ed.). New York: Macmillan.

Gorski, P. C. (2005). Multicultural Education and the Internet (2nd ed.). New York: McGraw-Hill Higher Education.

Gorski, P., \& Pothini, S. (2014). Case Studies on Diversity and Social Justice Education. New York, NY: Routledge.

Greeberg, D. N., Clair, J. A., \& Maclean, T. L. (2007). Enacting the Role of Management Professor: Lessons from Athena, Prometheus, and Asclepius. Journal Management Education, 6(4), 439-457.

Hallinger, P. (2003). Leading Educational Change: Reflections on the Practice of Instructional and Transformational Leadership. Cambridge Journal of Education, 33(3), .35-70. https://doi.org/10.1080/0305764032000122005

Hamalik, O. (2010). Management Curriculum Development. Bandung: Remaja Rosdakarya.

Hannum, E., Liu, J., \& Frongillo, E. A. (2013). Poverty, food insecurity and nutritional deprivation in rural China: Implications for children's literacy achievement. International Journal of Educational Development, (34), 90-97.

Hermino, A. (2014). Educational Leadership in the Globalization Era. Jogyakarta: Pustaka Pelajar

Hermino, A. (2016). Anger Management for Student. Theoretical and Practical Studies in the Educational Management. Jogyakarta: Pustaka Pelajar.

Hoffman, D. M. (1996). Culture and Self in Multicultural Education: Reflections on Discourse, Text, and Practice. American Educational Research Journal, 33(3), 545-569. https://doi.org/10.3102/00028312033003545

Jayne, M. Leh., Maike, G., \& John, A. G. (2015). Navigating the Development of Pre-Service Teachers' Intercultural Competence and Understanding of Diversity: The Benefits of Facilitating Online Intercultural Exchange. Journal for Multicultural Education, 9(2), 98-110. https://doi.org/10.1108/JME-12-2014-0042

Kadarusmadi. (1996). Parents Efforts in Reforming Education Situation in the Family. Unpublished Dissertation. Bandung: Postgraduate. IKIP Bandung.

Kalargyrou, V., Pescosolido, A. T., \& Kalargiros, E. A. (2012). Leadership Skills in Management Education. Academy of Educational Leadership Journal, 16(4), 39-63.

Kieu, T., \& Chau, N. H. (2000). Education in Vietnam. Journal of SEA Education, 1(1), 219-241.

Kopnina, H. (2013). Schooling the World: Exploring the critical course on sustainable development through an anthropological lens. International Journal of Educational Development, (62), 220-228. https://doi.org/10.1016/j.ijer.2013.10.002

Loomis, S., Rodriguez, J., \& Tillman, R. (2008). Developing Into Similarity: Global Teacher Education in The Twenty-First Century. European Journal of Teacher Education, 31(3), 233-245. https://doi.org/10.1080/02619760802208288

Mason, M. (2013). Educational inequality and educational quality. International Journal of Educational Development, (34), 1-2. 
Mayer, J. D., Salovey, P., \& Caruso, D. R. (2004). Emotionalle Inteligence. Theory, Findings, and Implications. International Journal of Psychological, 15(3), 197-215.

McAlpine, L., \& Amundsen, C. (2011). Doctoral Education: Research-Based Strategies for Doctoral Students, Supervisors and Administrators. New York: Springer. https://doi.org/10.1007/978-94-007-0507-4

McGill, J. (2013). International Student Migration: Outcomes and Implications. Journal of International Students, 3(2), 167-181.

Mertens, D. M. (2010). Research and Evaluation in Educational and Psychology (3rd ed.). California: SAGE Publications, Inc.

Mills, M. K., \& Quinn, A. J. (2013). Innovation in the Teaching of Sustainability in the Business Classroom Via a Combined model of Experiental Learning, Reflective Practice and Metaphor. International Journal of Organisational Behaviour, 17(3), 4-7.

Misco, T. (2007). Using Curriculum Deliberation to Address Controversial Issues: Developing Holocaust Education Curriculum for Latvian Schools. International Journal of Education Policy and Leadership, 2(8).

Mitaray, S. (2000). Education in the Lao People's Democratic Republic: Challenges in the New Millennium. Journal of Southeast Asian Education, 1(1).

Moolenaar, N. M., Daly, A. J., \& Sleegers, P. J. C. (2010). Occupying the Principal Position: Examining Relationships Between Transformational Leadership, Social Network Position, and Schools' Innovative Climate. Educational Administration Quarterly, 46(5), 623-670. https://doi.org/10.1177/0013161X10378689

Mulyasa, H. E. (2011). Character Education Management. Jakarta: Bumi Aksara.

Ndraha, T. (1997). Organizational Culture. Jakarta: Rineka Cipta.

Noor, R. M. (2012). The Hidden Curriculum. Building Character through Extracurricular Activities. Yogyakarta: Pedagogja.

Northouse, P. G. (2001). Leadership Theory and Practice (2nd ed.). Thousand Oaks, CA: Sage Publications, Inc.

Peng, W. J., McNess, E., Thomas, S., Wu, X. R., Zhang, C., Li, J. Z., \& Tian, H. S. (2013). Emerging Perceptions of Teacher Quality and Teacher Development in China. International Journal of Educational Development, (34), 58-66.

Rama, C. (2015). Cultural and Functional Diversity in the Elementary Classroom: Strategies for Teachers. Journal for Multicultural Education, 9(2), 54-67. https://doi.org/10.1108/JME-03-2015-0010

Reeves, D. B. (2006). The Learning Leader: How to Focus School Improvement for Better Results. Arkansas: ASCD.

Rivai, V. H., \& Murni, S. (2009). Education Management. Analysis Theory and Practice. Jakarta: Rajawali Pers.

Rodriguez, F. (2014). A Community College District Chancellor's View on Transformational Leadership. Journal of Transformative Leadership and Policy Studies, 4(1).

Sargent, T., Kong, P., \& Zhang, Y. (2013). Home environment and educational transitions on the path to college in rural northwest China. International Journal of Educational Development, (34), 98-106.

Schein, E. (1985). Organizational Culture and Leadership: A Dynamic View. San Francisco, CA: Jossey - Bass.

Scherrer, J. (2013). The Negative Effects of Student Mobility: Mobility as a Predictor, Mobility as a Mediator. International Journal of Education Policy and Leadership, 8(1).

Shockley, K. G. (2008). Africentric Education Leadership: Theory and Practice. International Journal of Education Policy and Leadership, 3(3).

Simon, M, BHK. (2010). Magazine OIKOS: To Services in Leadership. Malang: AXA Creative Design.

Skaalvik, E. M., \& Skaalvik, S. (2013). Teachers' Perceptions of The School Goal Structure: Relations with Teachers' Goal Orientations, Work Engagement, and Job Satisfaction. International Journal of Educational Development, (62), 199-209. https://doi.org/10.1016/j.ijer.2013.09.004

Slavin, R. E. (2006). Educational Psychology Theory and Practice. Boston: Pearson.

Soutworth, G. (2002). Instructional Leadership in School: Reflection and Empirical Evidence. School Leadership and Management, 22(1), 73-92. https://doi.org/10.1080/13632430220143042 
Spodek, B. (1982). Handbook of Research in Early Childhood Education. New York: Macmillan Publishing Co., Inc.

Stromquist, N. (2002). Education in a Globalized World: The Connectivity of Economic Power, Technology, and Knowledge. New York: Rouledge.

Tatto, M. T. (2006). Education Reform and The Global Regulation of Teachers' Education, Development, and Work: A Cross-Cultural Analysis. International Journal of Educational Research, 45(4-5), 231-241. https://doi.org/10.1016/j.ijer.2007.02.003

Tilaar, H. A. R. (2004). Multiculturalism; Global Challenges in Transforming the Future of Education. Jakarta: Grasindo.

Torres, C. A. (2002). Globalization, Education, and Citizenship: Solidarity versus Markets? American Educational Research Journal, 39(2), 363-378. https://doi.org/10.3102/00028312039002363

Twigg, D., Pendergast, D., Fluckiger, B., Garvis, S., Johnson, G., Robertson, J. (2013). Coaching for Early Childhood Educators: An insight into the effectiveness of an initiative. International Research in Early Childhood Education Journal, 4(1), 73.

Wiyani, N. A. (2012). Character Education Management. Concept and Implementation in Schools. Yogyakarta: Pedagogia.

World Education Forum Drafting Committee. (2000). Education For All: Meeting Our Collective Commitments, Expanded Commentary on the Dakar Framework for Action. Paris.

Yuan, W. (2011). Academic and Cultural Experiences of Chinese Students at an American University: A Qualitative Study. International Communication Studies.

\section{Copyrights}

Copyright for this article is retained by the author(s), with first publication rights granted to the journal.

This is an open-access article distributed under the terms and conditions of the Creative Commons Attribution license (http://creativecommons.org/licenses/by/4.0/). 